\title{
DEVELOPMENT OF THE EPIDEMIC
}

\section{Original names of virus \\ Human Tlymphotropic virus type III (HTLV III) Lymphadenopathy associated virus (LAV) \\ AIDS related/associated virus (ARV) \\ Now}

Human immunodeficiency virus (HIV)
The first recognised cases of the acquired immune deficiency syndrome (AIDS) occurred in the summer of 1981 in America. Reports began to appear of Pneumocystis carinii pneumonia and Kaposi's sarcoma in young men, whom it was subsequently realised were both homosexual and immunocompromised. Even though the condition became known early on as the acquired immune deficiency syndrome, its cause and modes of transmission were not immediately obvious. The virus now known to cause AIDS in a proportion of those infected was discovered in 1983 and given various names. The internationally accepted term is now the human immunodeficiency virus (HIV). More recently a new variant has been isolated, in patients with west African connections-HIV-II/LAV-II.

Diseases at least moderately indicative of underlying cellular immune deficiency

\begin{tabular}{|c|c|c|c|}
\hline $\begin{array}{l}\text { Cryptococosis } \\
\text { Histoplasmosis } \\
\text { Bacterial } \\
\text { "Atypical" } \\
\text { mycobacteriosis }\end{array}$ & $\begin{array}{l}\text { CNS or } \\
\text { disseminated } \\
\text { Oesophageal or } \\
\text { broncho- } \\
\text { pulmonary } \\
\text { Pulmonary, CNS, or } \\
\text { disseminated } \\
\text { Disseminated }\end{array}$ & $\begin{array}{l}\begin{array}{l}\text { Progressive multi- } \\
\text { focal leuco- } \\
\text { encephalopathy } \\
\text { Cancer } \\
\text { Kaposi's sarcoma } \\
\text { Cerebral lymphoma } \\
\text { Non-Hodgkin's } \\
\text { lymphoma }\end{array} \\
\begin{array}{l}\text { Lymphoreticular } \\
\text { malignancy }\end{array} \\
\begin{array}{l}\text { Others } \\
\text { Chronic lymphoid } \\
\text { interstitial } \\
\text { pneumonitis in } \\
\text { child under } 13\end{array}\end{array}$ & $\begin{array}{l}\text { No age restriction } \\
\text { Diffuse, } \\
\text { undifferentiated, } \\
\text { and of B cell } \\
\text { or unknown } \\
\text { phenotype } \\
>3 \text { months after an } \\
\text { opportunistic } \\
\text { infection }\end{array}$ \\
\hline
\end{tabular}

AIDS was originally defined by the Centers for Disease Control in America as occurring in a person:

$(a)$ with a reliably diagnosed disease that is at least moderately indicative of an underlying cellular immune deficiency - for example, Kaposi's sarcoma in a patient aged less than 60 years or an opportunistic infection.

(b) who has no known underlying cause of cellular immune deficiency or any other cause of reduced resistance reported to be associated with the disease.

This definition was used for surveillance purposes by most other countries. It was subsequently slightly modified in the light of the discovery of the causal agent and the development of laboratory tests to detect antibody and to include additional serious conditions (listed in the table). A further minor modification to take account of the changing clinical pattern will take place later this year.

NB Patients are excluded if they are anti-HIV negative and have normal Thelper lymphocyte counts and normal T helper: T suppressor ratios.

\section{Transmission of the virus}

\begin{tabular}{|c|c|}
$\begin{array}{l}\text { Sexual intercourse } \\
\text { Contaminated needles }\end{array}$ & $\begin{array}{c}\text { - Anal and vaginal } \\
\text { - Intravenous drug } \\
\text { abusers } \\
\text { Needlestick } \\
\text { injuries } \\
\text { Injections }\end{array}$ \\
Mother $\rightarrow$ child & - In utero \\
& - At birth \\
- ? Breast milk & - Semen \\
Organ/tissue donation & - Kidneys \\
& - Skin, bone marrow, \\
& corneas, heart \\
& valves, tendons, \\
& etc
\end{tabular}

HIV has been isolated from semen, cervical secretions, lymphocytes, cell free plasma, cerebrospinal fluid, tears, saliva, urine, and breast milk. This does not mean, however, that these fluids all transmit infection since the concentration of virus in them varies considerably. Particularly infectious are semen, blood, and possibly cervical secretions. The commonest mode of transmission of the virus throughout the world is by sexual intercourse. Whether this is anal or vaginal is unimportant. Other methods of transmission are through the receipt of infected blood or blood products and donated organs and semen. Transmission also occurs through the sharing or reuse of contaminated needles by injecting drug abusers or for therapeutic procedures and from mother to child. Transmission from mother to child occurs in utero and also possibly at birth. It is still uncertain whether the virus is transmitted through breast milk; only one case has been recorded of possible infection in this way. 


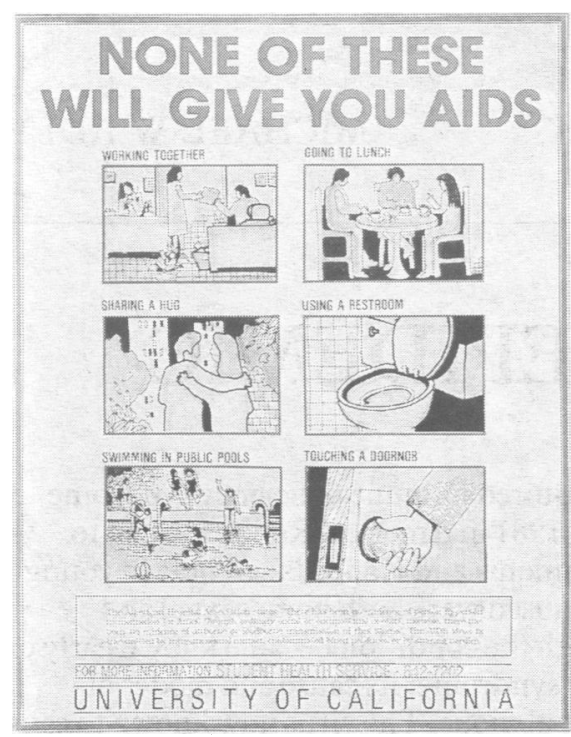

\section{Pattern of the epidemic}

AIDS in adults: patient groups in USA and UK up to March 1987

\begin{tabular}{lrrrr}
\hline & \multicolumn{2}{c}{ USA } & \multicolumn{2}{c}{ UK } \\
\cline { 2 - 5 } Patient groups & \multicolumn{1}{c}{ No } & $\%$ & No & $\%$ \\
\hline Homosexual man & 20678 & 66 & 640 & 88 \\
Intravenous drug user & 5344 & 17 & 10 & 1.5 \\
$\begin{array}{l}\text { Homosexual man and } \\
\text { intravenous drug user }\end{array}$ & 2433 & 7 & 8 & 1 \\
Haemophiliac & 266 & 1 & 28 & 4 \\
Received blood & 602 & 2 & 12 & 2 \\
Heterosexual contact & 1184 & 4 & 25 & 3 \\
Other/miscellaneous & 1019 & 3 & 1 & 0.5 \\
\hline & 31526 & 100 & 724 & 100 \\
\hline & \multicolumn{3}{c}{ Men 93\% } & \multicolumn{3}{c}{ Men 97\% } \\
\hline
\end{tabular}

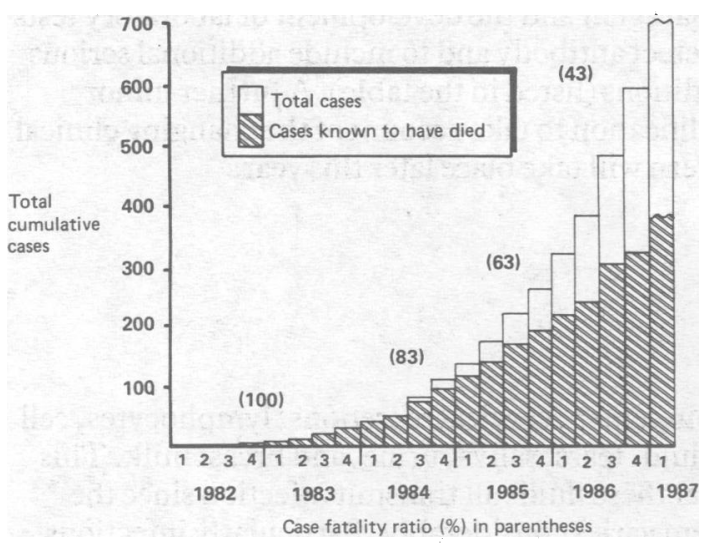

AIDS in the UK: Cumulative total quarterly cases reported to $\operatorname{CDSC}$ and $\operatorname{CD}(S) U$
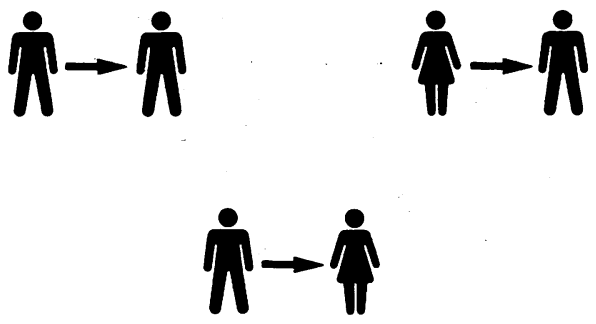

There is no well documented evidence that the virus is spread by saliva. It is not spread by casual or social contact. No health care workers have developed AIDS as a result of looking after patients with HIV infection and AIDS. There are, however, four reported cases of documented seroconversion among health care workers after needlestick injuries. The precautions and risks for such groups are covered in detail in a later article on control of infection policies. Finally, there is no evidence that the virus is spread by mosquitoes, lice, bed bugs, in swimming pools, or by sharing cups, eating and cooking utensils, toilets, and air space with an infected individual. Hence, HIV infection and AIDS are not contagious.

By March 1987, 31526 adult cases of AIDS had been reported in the USA plus an additional 456 paediatric cases. Most (79\%) of the cases in children occurred because a parent suffered from AIDS or belonged to a group at increased risk of AIDS; $12 \%$ occurred as a result of blood transfusions; and $5 \%$ occurred in children with haemophilia. Information on risk factors in the remaining $4 \%$ of parents of these children is not complete.

In the United States the rates for cases of AIDS per million of the population show wide geographical variation. New York has a rate of 991 per million, San Francisco 966, Miami 584, Newark 393, and Los Angeles 363 compared with 140 per million for the USA as a whole. In San Francisco and New York AIDS is now the major cause of premature death in young men. Adult cases in Europe totalled 4549 by December 1986 and in the United Kingdom 724 by March 1987. There are at least 25 times more people infected with HIV at any one time than have AIDS. In the UK proportionately more homosexuals have been notified than in America$89 \%$ of cases compared with $73 \%$. The doubling time of cases in the USA has slowed down since 1981-2. This slowing should not, however, detract from the projected trends. By 1991 there will probably be a cumulative total of 270000 cases in the USA.

In the USA and UK the first wave of the epidemic occurred in homosexual men, the next and current wave is among intravenous drug abusers, and after this it might affect the heterosexual population. Transmission into the heterosexual population will occur through bisexual men; intravenous drug abusers, and prostitutes. Currently in the United States $7 \%$ of cases (2369) have occurred among women, and, although the commonest risk factor is intravenous drug abuse (52\%), the next most common mode of transmission is heterosexual sexual contact (27\%). In the UK $2 \cdot 6 \%$ of adult cases (19) have occurred in women. Case reports and epidemiological surveys clearly show that the virus can be transmitted from men to women and from women to men. Studies of heterosexual transmission have shown different rates of transmission, with the female partners of men with AIDS showing the highest rates. Transmission from women with AIDS to their male partners has been reported to be as high as $65 \%$. To some extent these varying rates may be due to different study designs. 


\begin{tabular}{|lr|}
\hline \multicolumn{2}{|l}{ Heterosexual transmission rates } \\
Male $\rightarrow$ Female \\
Wives of seropositive haemophiliacs & $7-9 \%$ \\
Female partners of seropositive & \\
bisexual men & $14 \%$ \\
Female partners of seropositive & \\
patients with AIDS & up to $54 \%$ \\
$\begin{array}{l}\text { Female } \rightarrow \text { Male } \\
\text { Male partners of female AIDS } \\
\text { patients }\end{array}$ & up to $65 \%$ \\
\hline
\end{tabular}

In Africa strong evidence has accumulated that HIV is spread mainly by heterosexual intercourse. The male to female ratio of cases is virtually $1: 1$. As well as sexual intercourse, contaminated blood and also possibly needles used for therapeutic purposes and vertical transmission are important. It is now recognised that cases of AIDS were first seen in central Africa in the late 1970s. Surveys from some African countries show that the prevalence of infection is high among certain groups $-80-90 \%$ of prostitutes, $30 \%$ of their male clients, $30 \%$ of those attending departments for sexually transmitted diseases, $10 \%$ of blood donors, and $10 \%$ of women attending antenatal clinics. Even though the high levels of infection were originally confined to central Africa, the virus and disease are spreading throughout most of that continent.

\section{Relation between the virus and the disease}

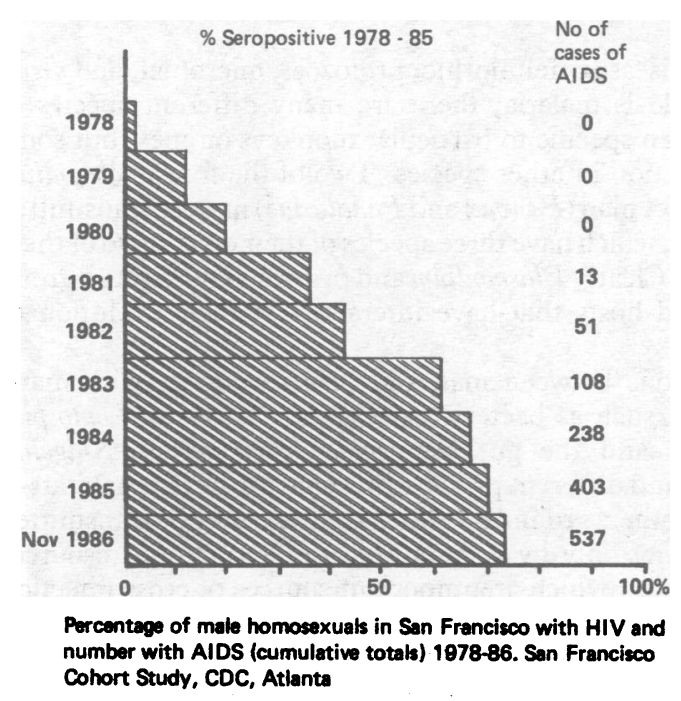

Prevalence (\%) of anti-HIV in homosexual men attending departments of genitourinary medicine

\begin{tabular}{lcc}
\hline & London & Provinces (5 cities) \\
\hline 1982 & 3.7 & \\
1983 & & \\
1984 & 21.0 & 5.1 \\
1985 & 35.0 & 11.0 \\
\hline
\end{tabular}

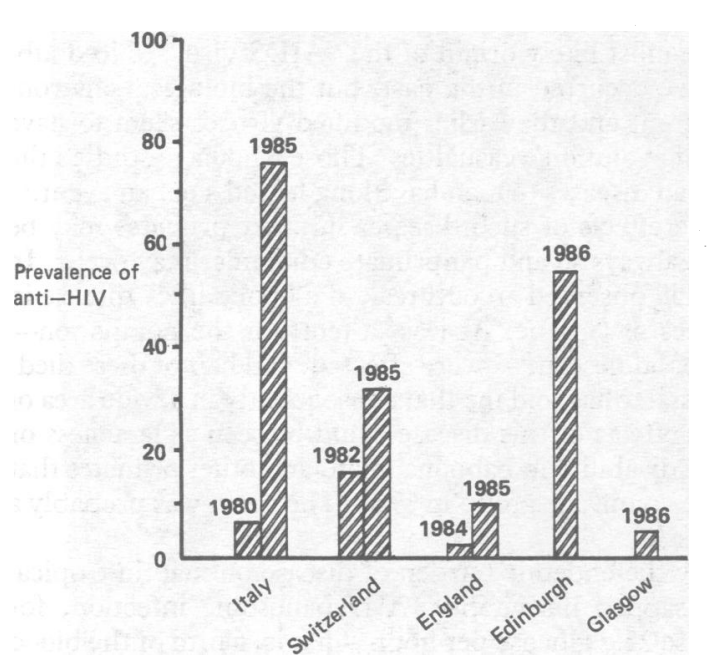

The advent of an effective antibody test in 1984 has allowed for a clearer understanding of the changing prevalence and natural history of HIV infection. For example, tests on stored samples of serum collected for other reasons from a cohort of homosexual men in San Francisco give an indication of how the epidemic evolved. In 1978, 4\% were anti-HIV positive; by 1980 the proportion had increased sixfold, to $24 \%$. In London and British provincial centres the rate of seropositivity has also increased. These surveys show that the proportion of individuals infected needs to be high before cases of AIDS start to become apparent. It also underlines the importance of health education campaigns early in the epidemic, when the seroprevalence is low. Once cases start to appear the epidemic drives itself and a much greater effort is required in terms of control and medical care.

The rate of infection has also increased in other groups. In southern Italy the prevalence of HIV antibody among intravenous drug users increased from $6 \%$ in 1980 to $76 \%$ in 1985 . Similar large increases have been seen in European countries such as Switzerland. In the UK the prevalence variesfrom $10 \%$ in London to $54 \%$ in Edinburgh. This geographical variation is also seen in the USA, with low rates in San Francisco and New Orleans (less than 5\%) and high rates in Manhattan and northern New Jersey (greater than $50 \%$ ). Haemophiliacs are the final group with a high rate of infection in the UK (an average national figure of $44 \%$ ). The level of infection in prostitutes tested in the UK and Europe is low, ranging from $0 \%$ in Italy, France, and England to $6 \%$ in Greece. Once prostitutes who are also intravenous drug addicts are studied the rate is very much higher-for example, $70 \%$ in Italy.

AIDS results in a considerable cost not only in human suffering but also to the health service. In New York the estimated lifetime hospital cost of looking after a patient with AIDS is $\$ 134000$, whereas in San Francisco it is $\$ 25000-\$ 32000$. In the UK it is $£ 7000-\$ 20000$. These figures take into account only hospital costs. Other costs include time off work, the effect of the deaths of young people on national productivity, and domiciliary services. AIDS represents the most major public health problem in the world this century. A clear understanding of the epidemiology forms the basis of developing a strategy of control ranging from health education to research.
Professor Michael W Adler, MD, FRCP, is professor of genitourinary medicine, Middlesex Hospital and Medical School, London.

The second table, showing diseases indicative of immune deficiency, is reproduced, by permission, from Weller IVD. AIDS. In: Adler MW. ABC of Sexually Transmitted Diseases. BMJ, 1985. 